Araştırma Makalesi - Research Article

\title{
Tek Fazlı AA Gerilim Denetleyicilerde Güç Faktörü ve Harmonik Bozulma Arasındaki İlişkiyi Belirlemek için Deneysel Bir Çalışma
}

\author{
Muhammed Reşit ÇORAPSIZ ${ }^{*}$, Hakan KAHVECI ${ }^{2}$, Muhammed Fatih ÇORAPSIZ ${ }^{3}$ \\ Geliş / Received: 14/11/2019 \\ Revize / Revised: 09/04/2020 \\ Kabul / Accepted: 21/05/2020

\section{$\ddot{\mathbf{O Z Z}}$}

$\mathrm{Bu}$ makale, tek fazlı bir AA (TFAA) gerilim kontrolörlerinde güç faktörü ile harmonik bozulma arasındaki ilişkinin belirlenmesi ile ilgilidir. Bu çalışmanın amacı, farklı faz tetikleme açıları (FTA) sırasında güç faktörü (GF) ve toplam harmonik bozulmanın (THB) değişimini araştırmaktır. İlk olarak, yüksek frekanslarda çalışan tek fazlı AA gerilim denetleyicilerde triyak yerine tristör kullanmanın avantajlarından bahsedilmiştir. İkinci olarak, tek fazlı AA gerilim denetleyicileri için güç faktörü ve toplam harmonik bozulmalar teorik olarak incelenmiştir. Son olarak, güç faktörü ve toplam harmonik bozulma arasındaki ilişki hem benzetim hem de deneysel çalışmalar ile gösterilmiştir. Bununla birlikte, düşük çıkış gerilimlerinde, güç faktörünün (GF) oldukça azaldığı ve toplam harmonik bozulmasının (THB) önemli ölçüde arttığı gözlenmiştir.

Anahtar Kelimeler- Tek Fazlı AA (TFAA) Gerilim Denetleyicileri, Faz Tetikleme Kontrolü, Güç Faktörü (GF), Toplam Harmonik Bozulma (THB), Matlab-SIMULINK.

\footnotetext{
1*Sorumlu yazar iletişim: rcorapsiz@bayburt.edu.tr (https://orcid.org/0000-0001-5477-5299)

Elektrik ve Enerji Bölümü, Bayburt Üniversitesi, Teknik Bilimler Meslek Yüksekokulu, 69000, Bayburt, Türkiye

2İletișim: hknkahveci@ktu.edu.tr (https://orcid.org/0000-0001-9369-2330)

Elektrik-Elektronik Mühendisliği, Karadeniz Teknik Üniversitesi, Mühendislik Fakültesi, 61080, Trabzon, Türkiye

3İletişim: corapsiz@atauni.edu.tr_(https://orcid.org/0000-0001-5692-8367)

Elektrik-Elektronik Mühendisliği, Atatürk Üniversitesi, Mühendislik Fakültesi, 25000, Erzurum, Türkiye
} 


\title{
An Experimental Study to Determine the Relationship Between Power Factor and Harmonic Distortion in Single-Phase AC Voltage Controller
}

\begin{abstract}
This paper deals with the determination of the relationship between the power factor and the harmonic distortion in a single-phase AC (SPAC) voltage controller. The aim of this study is to investigate the change of power factor (PF) and total harmonic distortion (THD) during different phase triggering angles (PTA). Firstly, the advantages of using thyristor instead of triac in single-phase AC voltage controllers operating at high frequencies are mentioned. Secondly, the power factor and total harmonic distortions for single-phase AC voltage controllers are theoretically examined. Finally, the relationship between power factor and total harmonic distortion are demonstrated by both simulation and experimental studies. However, it is monitored that, at lower output voltages, the power factor (PF) is pretty much reduced and total harmonic distortion (THD) is significantly increased.
\end{abstract}

Keywords- Single-Phase AC (SPAC) Voltage Controller, Phase Triggering Control (PTC), Power Factor (PF), Total Harmonic Distortion (THD), Matlab-SIMULINK. 


\section{INTRODUCTION}

The main advantage of the SPAC voltage controller topology is the fact that it can generate an output $\mathrm{AC}$ voltage lower than the input $\mathrm{AC}$ voltage, depending on the phase triggering angle (PTA). In AC systems, it is desired that both the input voltage and the load voltage pure sine. In addition, due to the non-linear semiconductor elements and non-linear loads, the load voltage is generally not in the form of pure sine. For this reason, occur distortions on both the load voltage and the grid voltage. These distortions produce harmonics. On the other hand, harmonics distort the shape of the sine signal and adversely affect both the power factor and the power quality. In this study, the power factor and harmonic analysis of the single-phase voltage controller with phase triggering control were realized both simulation and experimentally. It can be said that power factor and harmonic distortion are two important parameters that affect the efficient operation of AC systems. Efforts to obtain different levels of voltage or current have led researchers to develop different energy conversion topologies. Obtaining the desired level of voltage is as important as generating and transmitting it. Many electrical devices, especially in industrial applications, require different voltage or current levels to operate. Instead of producing these current and voltage levels specifically for each device, it is much more efficient to adjust the value of a constant source to the desired current and voltage levels by means of a voltage controller. Single-phase AC voltage controllers, which have an important place in rapidly developing power electronics circuit topologies, provide power flow by adjusting the effective value of the output voltage between the effective value of the input voltage and zero. A semiconductor switch/switches is placed between the AC input source and the load, capable of switching at high frequency. This switch can be thyristor or triac. For applications up to $400 \mathrm{~Hz}$, triacs are used as long as they meet the power requirements, but at higher frequencies, the use of thyristors is more common [1]. As is known, a triac equivalent can be obtained by connecting the two thyristors anti-parallel. SPAC voltage controllers are widely used in lighting control, induction heating, domestic heating, tap changeover of load transformers and speed control of single-phase induction motors [2]. Although phase triggering control is simple in design, this technique suffers from harmonic distortion and low power factor problems. In order to eliminate these problems, different PWM techniques have been developed [3]. In [4], the power quality analysis of the AC chopper used in heating systems in chemical tests and research laboratories at variable phase angles were examined. In [5], speed control of a single-phase induction motor with AC chopper was performed. They examined both phase and PWM controlled AC choppers and indicated that PWM control is more appropriate in terms of harmonic distortion and power factor. In [6], the AC chopper was designed using IGBT instead of a thyristor or triac, and the differences of the study from the classical AC chopper circuit were demonstrated.

In this study, single-phase $\mathrm{AC}$ voltage controllers with phase triggering control have been investigated. Firstly, mathematical expressions have been obtained with the help of the electrical equivalent circuit. Then, these expressions are modelled in Matlab/Simulink environment and the output voltage is observed with different phase triggering angles. The chopper switch is realized using two thyristors connected in anti-parallel to each other. The main advantage of this structure is that it can be controlled more easily since a small number of switching elements are used compared to other AC voltage controller structures. In addition, the effects of the change of the phase triggering angle on the power factor of the system are investigated. The harmonic analysis is performed for the results obtained from the simulation. Finally, the experimental setup is prepared and the output voltage compared with the theoretical and simulation results.

\section{MATERIAL AND METHOD}

\section{A. Electrical and Mathematical Analysis}

As mentioned previously, the triac has advantageous at low frequencies due to the low number of legs. But, generally at high frequencies, the thyristor equivalent is preferred. This is because the thyristor has a high switching frequency. Figure 1a, shows the structure of a triac and Figure 1b, shows the thyristor equivalent of this structure. 


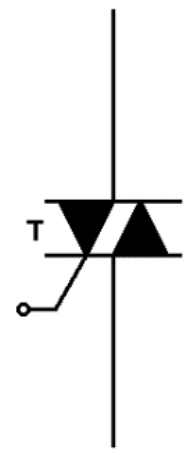

a.)

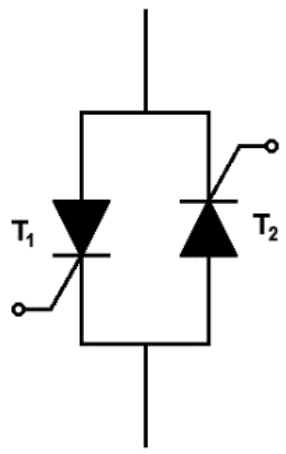

b.)

Figure 1. a.) Structure of a Triac b.) Thyristor equivalent of triac

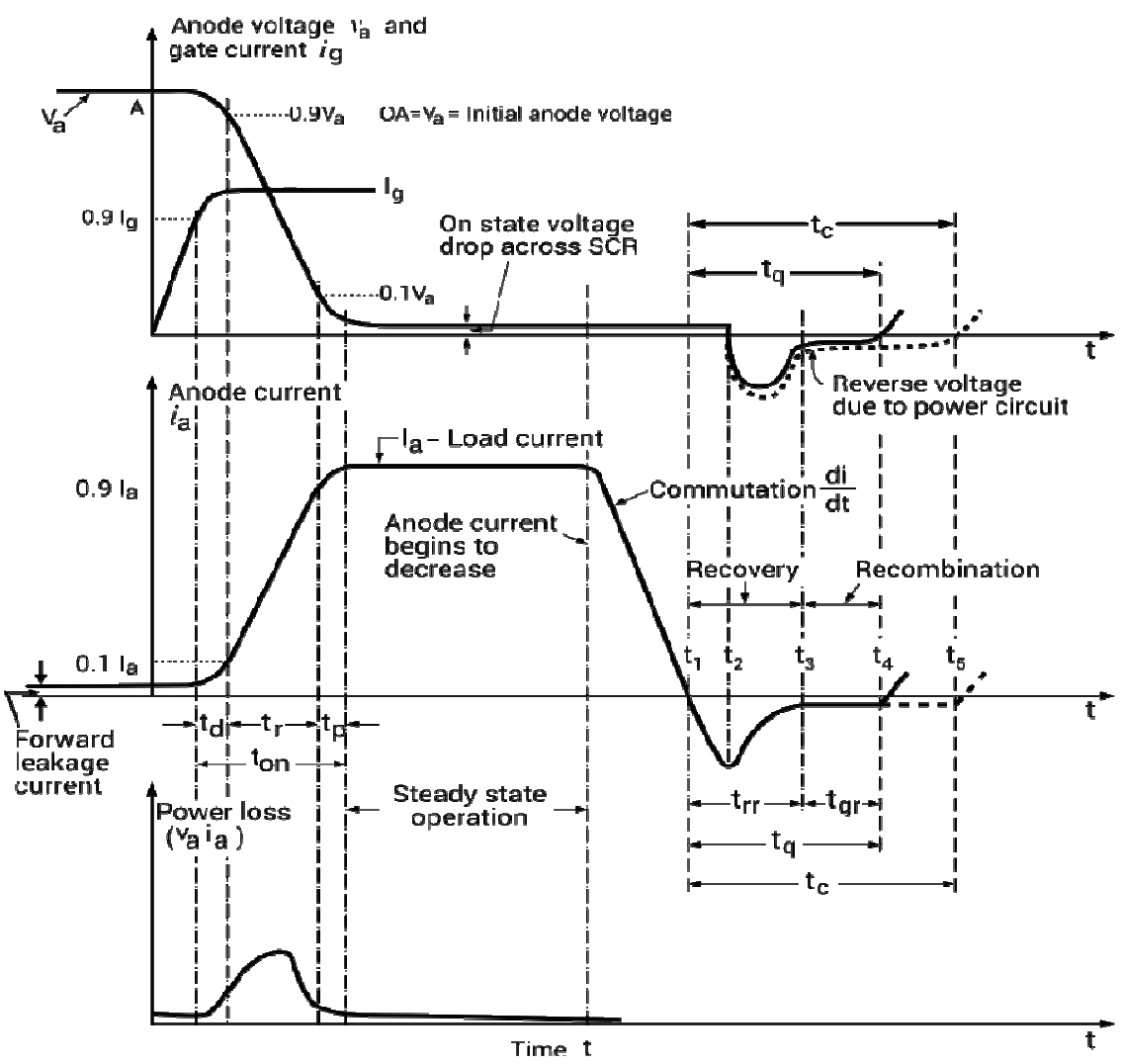

Figure 2. Switching characteristics of Thyristor (SCR) [7].

Furthermore, the dynamic switching characteristic of the thyristor (SCR) is shown in Figure 2. When a positive gate signal is applied to a forward-biased SCR, the transition of SCR from blocking state to conducting state is called as turn-on region and the time taken for SCR to traverse from the blocking state to conducting state is called as turn-on time [8]. And turn-on time defined as given in Eq.1,

$$
t_{\text {on }}=t_{d}+t_{r}+t_{p}
$$

Where $t_{d}$ is delay time, $t_{r}$ is rising time and $t_{p}$ is spread time. The thyristor turn-off operation is realized in two ways. The first is reducing the anode current below its holding current level and the second is the 
application of reverse voltage. When a reverse voltage is applied to a thyristor in the conduction state, the thyristor current decreases to zero at $t_{1}$. However, since the carriers are in the conduction state, the anode current starts to flow in the opposite direction with the same slope and reaches its maximum value in time $t_{2}$. At the end of time $t_{3}$, this current is assumed to fall below the holding current. Thus, the thyristor is automatically turn-off until the moment $t_{4}$. To realize the turn-off operation, a positive voltage must not be applied to the anode end during the period $t_{q} . t_{c}$ is defined as the circuit switch-off time and must be greater than $t_{q}$ for reliable commutation. Therefore, reverse recovery time $t_{r r}$ and gate recovery time $t_{g r}$ is are expressed as seen in Eq.2,

$$
\begin{aligned}
& t_{r r}=t_{3}-t_{1} \\
& t_{g r}=t_{4}-t_{3}
\end{aligned}
$$

The $t_{r r}$ and $t_{g r}$ are two important parameters for semiconductor elements and determine the operating frequency of semiconductor elements. Single-phase AC voltage controllers use thyristors at frequencies of 400 $\mathrm{Hz}$ and above because $t_{r r}$ and $t_{g r}$ times are shorter than triacs. Two different control methods are available in practice to control power flow with SPAC voltage controllers. The first one is On/Off control and the second is phase triggering control. In the On/Off control method, the thyristors, which are connected between the input AC source and the load, are electrically switched on and off for several periods to provide power flow. This can be similar to the operation of a contactor capable of switching at high speed. In the phase triggering control method, the anti-parallel thyristors are connected between the AC input and the load. However, for each half-period of the input, the thyristors are switched on and off at a specific switching frequency. In this case, the value between the phase triggering angle and the half-period of the input voltage is appearing on the load. By adjusting the phase triggering angle, the effective value of the output voltage is changed and thus the power flow is controlled. The switch off of the thyristors is performed by the line since the input voltage is AC (line commutation). Therefore, since there is no extra commutation circuit in the AC voltage controllers the circuit structures are quite simple. The quality of the AC voltage controllers is measured by total harmonic distortion and power factor. For an efficient operation, the total harmonic distortion should be as low as possible and the input power factor should be as high as possible [9].

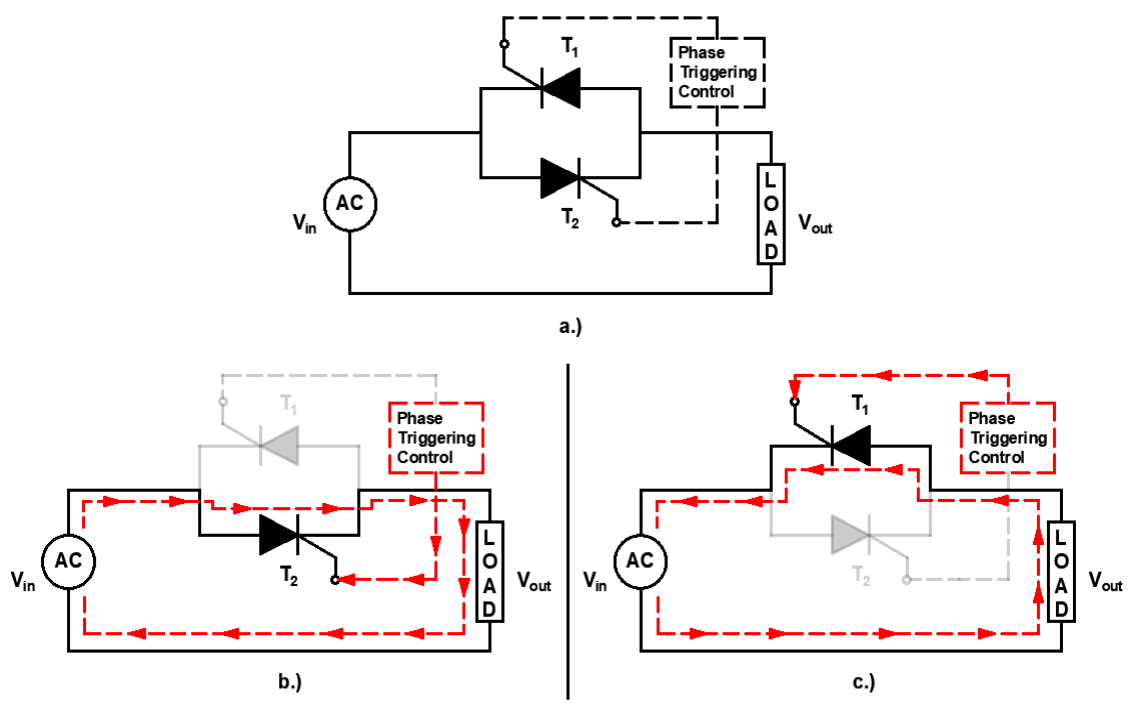

Figure 3. Electrical equivalent circuit of SPAC voltage controller

The electrical equivalent circuit of the SPAC voltage controller is shown in Figure 3. In Figure 3a, the thyristors $T_{1}$ and $T_{2}$ are connected in anti-parallel and placed between the load and the AC source. In Figure $3 b$, the switch $T_{2}$ is switched on, depending on the magnitude of the phase triggering angle, and the load is connected directly to the source. In Figure $3 \mathrm{c}$, the $T_{l}$ switch performs this operation. The phase triggering angle is varied 
between 0 and $180^{\circ}$ to control the effective value $(R M S)$ of the output voltage. The effective value of the output voltage can be expressed with Eq.3,

$$
V_{o(R M S)}=\left[\frac{1}{T}\left(\int_{\alpha}^{T}\left(V_{m} \sin \omega t\right)^{2} d(\omega t)\right)\right]^{1 / 2}
$$

Eq. (3) can be expressed in terms of input voltage and phase triggering angle as given in Eq.4,

$$
V_{o(R M S)}=V_{i n}\left[\frac{1}{\pi}\left((\pi-\alpha)+\frac{\sin 2 \alpha}{2}\right)\right]^{1 / 2}
$$

Where, $V_{o(R M S)}$ represents the effective value of the output voltage, $V_{\text {in }}$ the input voltage, $\alpha$ phase triggering angle in radian, $T$ electrical period, $\omega$ angular velocity, respectively. As seen in Eq. (4), the effective value of the output voltage is equal to the effective value of the input voltage for the zero value of the phase triggering angle. Hence, the SPAC voltage controllers perform power flow between the effective value of the input voltage and zero. In addition, the variation of the $P F$ must be taken into account when realizing the power flow. The output effective power can be expressed as given in Eq. (5).

$$
P_{o(R M S)}=I_{o(R M S)}^{2} R_{L}
$$

$P F$ is defined as the ratio of the output effective power to the input effective power. Also, $P F$ is one of the two most important parameters limiting the application of AC voltage controllers and can be expressed as in Eq. (6).

$$
P F=\frac{I_{o(R M S)}{ }^{2} R_{L}}{V_{i n(R M S)} I_{i n(R M S)}}
$$

Where, $P F$ represents the power factor, $I_{o(R M S)}$ the effective value of the output current, $R_{L}$ load, $V_{i n(R M S)}$ and $I_{i n(R M S)}$ the effective values of the input voltage and input current, respectively. The other parameter affecting the performance of AC voltage controllers is the THD. Harmonics are very important for the electricity grid. In order to connect a system to the electricity grid, both the $P F$ and the $T H D$ must be at a certain level. Power electronic circuits, which become widespread day by day, cause harmonic distortion in electrical networks. In addition, harmonic distortion is often caused by non-linear loads. Photovoltaic systems, inductors, and circuits containing semiconductor elements are an example of these loads. When these loads are connected to the grid, they cause harmonic currents and voltages.

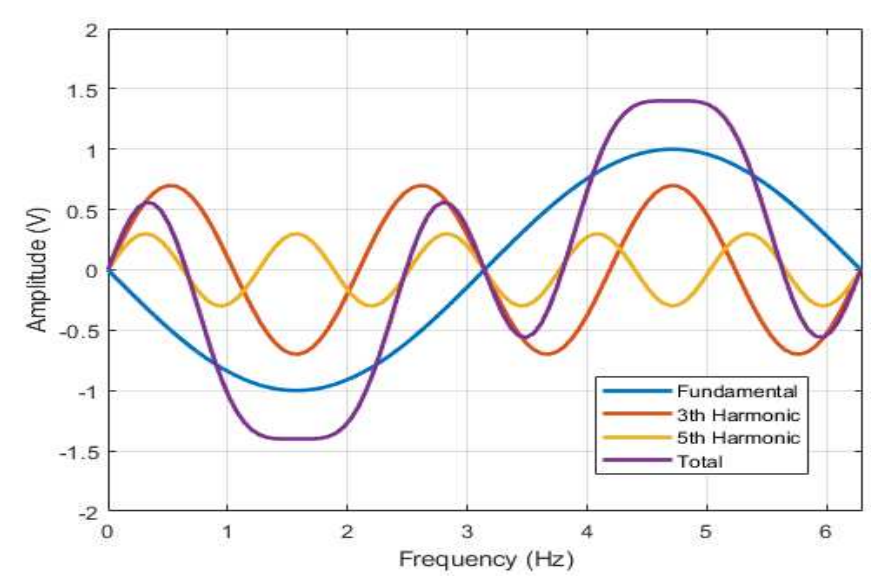

Figure 4. Harmonic distortion 


\begin{tabular}{|c|c|c|}
\hline & $\begin{array}{l}\text { BŞEÜ Fen Bilimleri Dergisi } \\
7(1), 306-318,2020\end{array}$ & $\begin{array}{r}\text { BSEU Journal of Science } \\
\text { DOI: } 10.35193 / \text { bseufbd.647049 }\end{array}$ \\
\hline U & & $8-7575$ (http://dergipark.gov.tr/bseufbd) \\
\hline
\end{tabular}

However, these loads do not change the grid frequency. Figure 4 shows the fundamental component of a voltage signal, the third and fifth harmonics and mains voltage signal consisting of their sum. As can be seen, harmonics have negative effects on the grid voltage. Because of these effects, the grid voltage is usually not in the form of a pure sine. Therefore, oscillations occur on the grid voltage. These oscillations can be expressed as given in Eq. 7 the sum of the components (harmonics) at the fundamental frequency and other frequencies by means of Fourier analysis.

$$
f(t)=\frac{a_{0}}{2}+\sum_{n=1}^{\infty}\left[\left(a_{n} \cos n \omega t\right)+\left(b_{n} \sin n \omega t\right)\right]
$$

Where, $a_{0}$ represents the average value, $n$ the harmonic coefficient, $a_{n}$ and $b_{n}$ the Fourier coefficient of the $f(t)$, respectively.

\section{B. Design of Simulation Model}

The simulation model of the SPAC voltage controller with phase triggering control (PTC) is shown in Figure 5. This model realized by considering the electrical equivalent circuit in Figure 3, Eqs. (4) and (6).

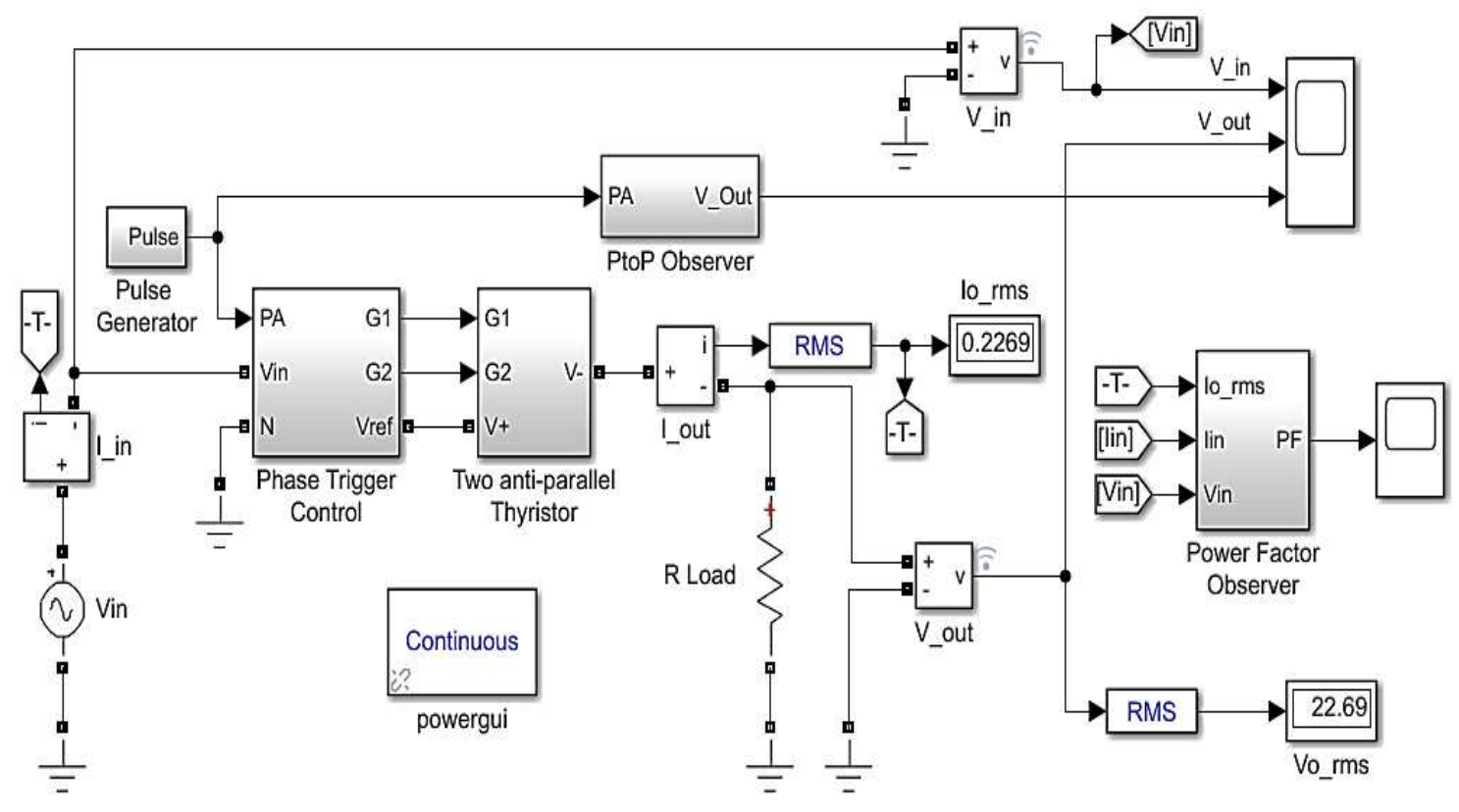

Figure 5. Simulation model of SPAC voltage controller with PTC

In Figure 5, the phase trigger control block determines the zero-crossing points of the AC voltage signal supplied from the input and generates the phase triggering angles $(G 1, G 2)$. Between these angles, there should be a $180^{\circ}$ phase difference during an electrical period. In addition, phase triggering angles given from input this block are converted to seconds using source frequency [10]. Inside the two anti-parallel thyristor block, there are two thyristors connected in anti-parallel to each other, which are supplied with the input voltage. Peak values of the output voltage in positive and negative periods were monitored with PtoP observer block. The power factor observer block, which was designed with Eq. (6) in mind, was used to monitor the variation of the power factor depending on the phase triggering angles. 


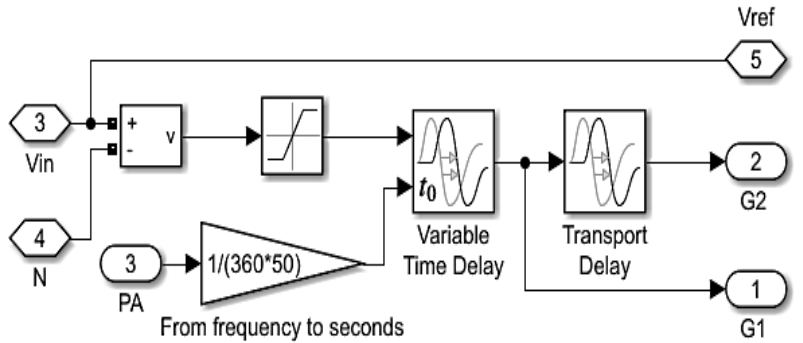

a.)

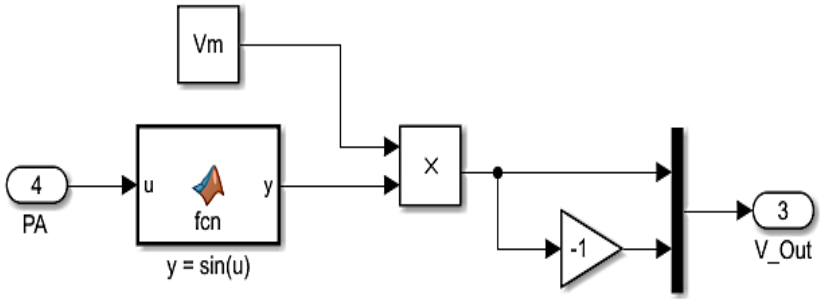

c.)

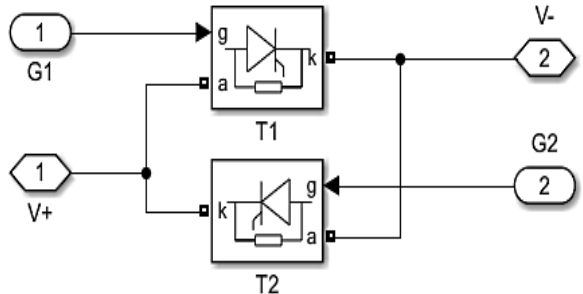

b.)

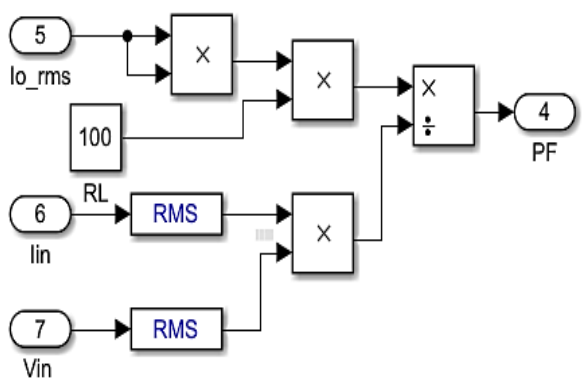

d.)

Figure 6. Internal structure of simulation blocks, a.) Phase triggering control, b.) Two anti-parallel thyristor, c.) Peak to peak observer, and d.) Power factor observer

The internal structures of the blocks used in the simulation model are shown in Figure 6. In Figure 6a, the input voltage was saturated to obtain the reference voltage. Variable time delay block generates positive phase triggering angles, while variable transport delay generates negative phase triggering angles. There must be a $180^{\circ}$ phase difference between the positive and negative phase triggering angles. On the other hand, the gain block was used to convert the phase triggering angles from the frequency to the seconds. Fig. $6 \mathrm{~b}$ shows the triac equivalent obtained by connecting anti-parallel two thyristors. Thyristors are generally preferred for AC voltage controllers since the reverse recovery time $\left(t_{r r}\right)$ is shorter than triac. Fig. $6 \mathrm{c}$ shows the peak to peak observer for measuring the value of the output signal relative to the phase triggering angle.

This block was used to control peak value at both the positive and negative half periods of the output signal. The power factor observer block is shown in Figure 6d. This block was realized with the help of a mathematical expression of power factor. With this block, change of power factor according to phase triggering angles was observed.

\section{Experimental Setup}

The experimental setup is shown in Figure 7. In the experimental setup, the AC grid voltage of $220 \mathrm{~V} / 50 \mathrm{~Hz}$ has been reduced to $55 \mathrm{~V} / 50 \mathrm{~Hz}$ with the help of the transformer. A symmetrical $15 \mathrm{~V}$ DC power supply has been used to energize the reference voltage, single-phase control unit, and measuring modules. This DC voltage is generated by an AC/DC converter using the grid voltage supplying the experimental setup. In order to control the effective value of the output voltage, two independent thyristor groups were connected in anti-parallel. This connection can be assumed to be equal to a triac model. 


\begin{tabular}{|c|c|c|}
\hline & $\begin{array}{l}\text { BŞEÜ Fen Bilimleri Dergisi } \\
7(1), 306-318,2020\end{array}$ & $\begin{array}{l}\text { BSEU Journal of Science } \\
\text { DOI: } 10.35193 / \text { bseufbd } 647049\end{array}$ \\
\hline & & 58-7575 (http://dergipark.gov.tr/bseufbd) \\
\hline
\end{tabular}

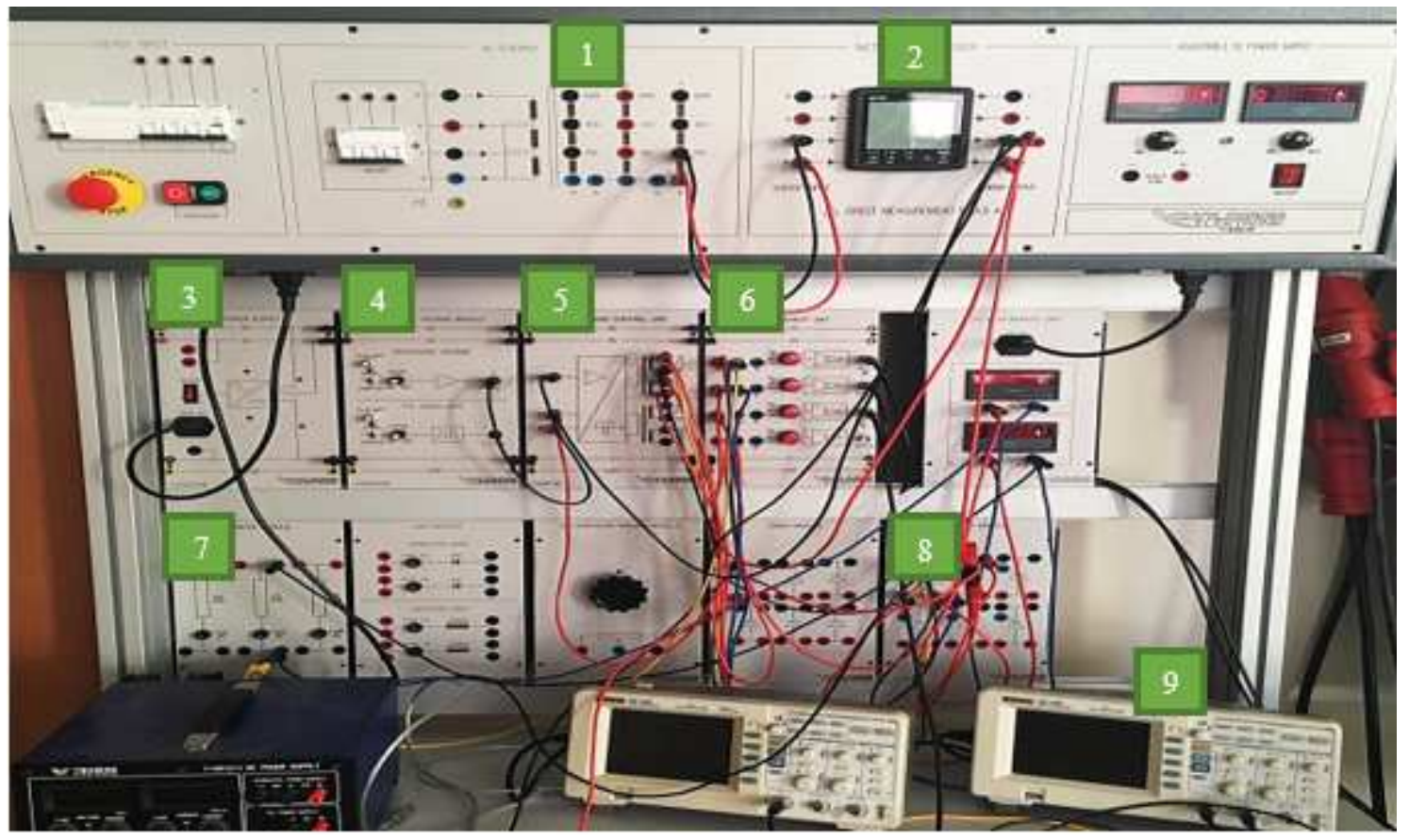

Figure 7. Experimental setup

The modules used in the experimental setup shown in Figure 7 are as follows,

1) $220 / 55-50 \mathrm{~Hz}$ Transformer,

2) Network analyzer for measuring phase voltage, phase current and power factor,

3) $\mathrm{AC} / \mathrm{DC}$ converter, symmetrical $15 \mathrm{~V}$,

4) Reference voltage module for the zero-crossing point in AC grid voltage,

5) Single phase control unit for the produce phase triggering angles,

6) and 9.) Measurement unit,

7) Load groups,

8) Two anti-parallel thyristor groups.

In the operation of the experimental setup, firstly, the AC input voltage was applied to the single-phase control unit and the reference voltage was obtained. With the help of a single-phase control unit, control signals were generated which is proportional to the reference voltage and based on the grid voltage zero-crossing points. These signals were applied to the thyristor group connected in anti-parallel to control the effective value of the output voltage under the $100 \Omega$ load. Since it is not possible to numerically adjust the phase triggering angles in the experimental setup, reference triggering angles have been tried to be obtained by means of the potentiometer. Reference phase triggering angles were selected at $30^{\circ}, 60^{\circ}, 90^{\circ}$ and $120^{\circ}$. The block diagram of the experimental setup is shown in Figure 8. 


\begin{tabular}{|c|c|c|}
\hline & $\begin{array}{l}\text { BŞEÜ Fen Bilimleri Dergisi } \\
7(1), 306-318,2020\end{array}$ & $\begin{array}{l}\text { BSEU Journal of Science } \\
\text { DOI: } 10.35193 / \text { bseufbd } 647049\end{array}$ \\
\hline & & 58-7575 (http://dergipark.gov.tr/bseufbd) \\
\hline
\end{tabular}

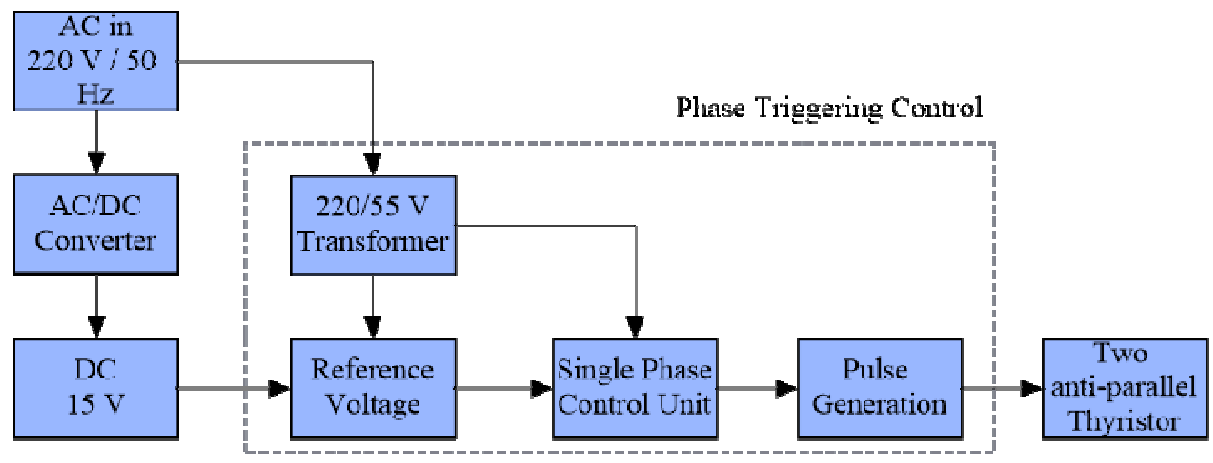

Figure 8. Block diagram of experimental setup

\section{RESULT AND DISCUSSION}

The simulation results of the designed model are shown in Figure 9. In the results, input voltage (green line) and the output voltage (red line) were compared. The designed phase triggering control model was successful monitored the given reference phase angles. In Figure 9a, the phase triggering angle is selected as $\alpha=30^{\circ}$. As can be seen from Figure 9b, when the phase triggering angle is increased to $\alpha=60^{\circ}$ degrees, it is clear that the effective value of the input voltage on the load is reduced compared to the previous case. Hence, keeping small of the phase triggering angle is highly effective in increasing the output effective voltage.
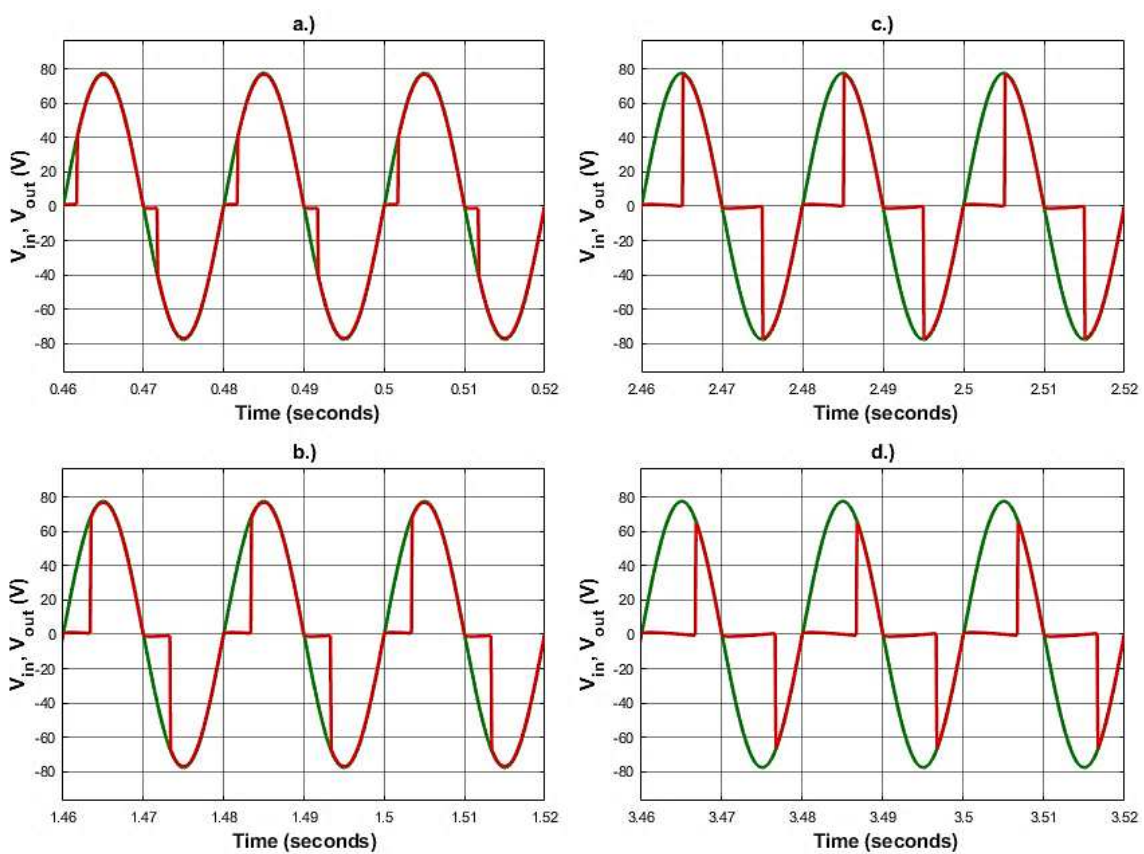

Figure 9. Change of output voltage with respect to input voltage in the designed simulation model, a.) $\alpha=30^{\circ}$, b.) $\alpha=60^{\circ}$, c.) $\alpha=90^{\circ}$, and d.) $\alpha=120^{\circ}$

Therefore, the amplitude of the phase triggering angle ranging from 0 to 180 degrees is inversely proportional to the effective value of the output voltage. At the moment when the phase triggering angles are $90^{\circ}$ and $120^{\circ}$, the time-dependent variation of the output and the input voltage is shown in Figures $9 \mathrm{c}$ and $9 \mathrm{~d}$, respectively. The increase of the phase triggering angle meaning the reduction of the effective value of the output voltage. This case adversely affects power factor and causes inefficiently run of the voltage controller. 

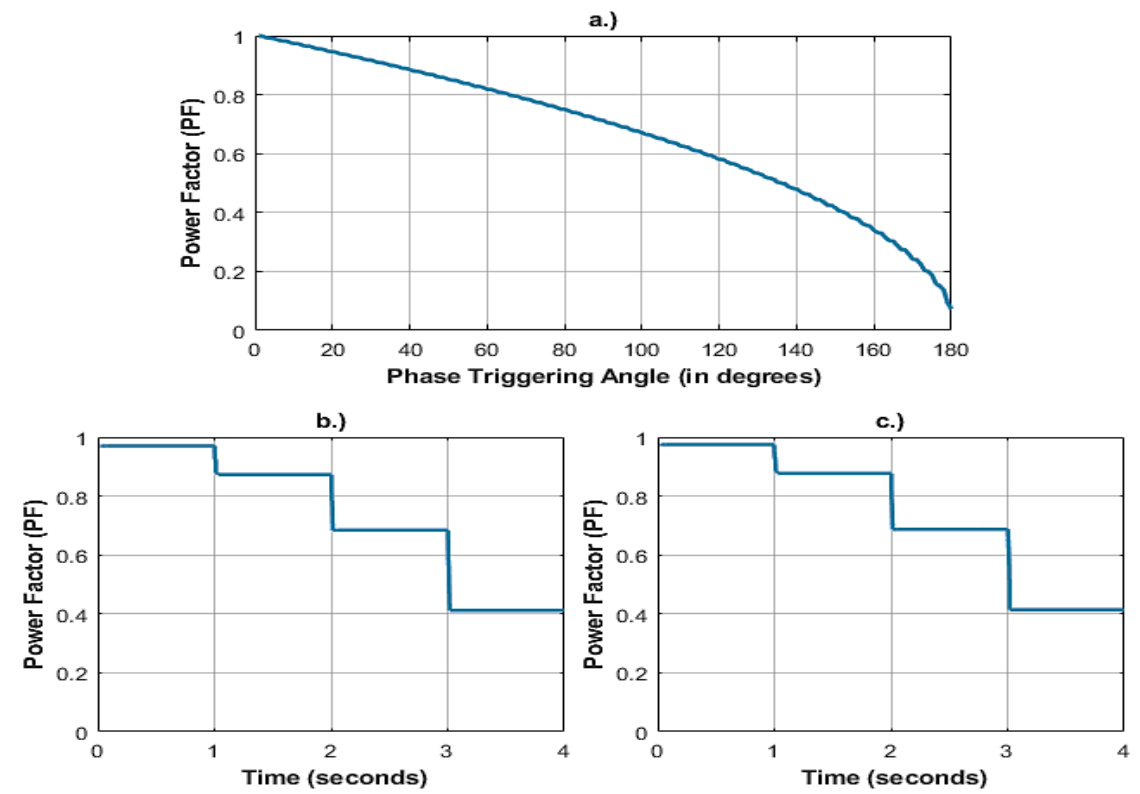

Figure 10. a.) Change of power factor versus phase triggering angle, and b.) Change of power factor versus time in the designed simulation model, c.) Change of power factor versus time in the designed experimental model

Figure 10a shows the variation of the power factor for the single-phase AC voltage controller with respect to the phase triggering angle. As can be seen from Figure 10a, the controller power factor varies inversely proportional to the phase triggering angle. This is one of the biggest problems of AC voltage controllers. Figure $10 \mathrm{~b}$ and $10 \mathrm{c}$ shows the change of power factor versus reference phase triggering angles applied to the designed single-phase voltage controller in $0,1,2,3 \mathrm{sec}$. simulation and experimental model, respectively. As can be seen from Figure 10b, when the phase triggering angle is applied at $30^{\circ}$ (interval 0 1sec.), the power factor is 0.97 , and when the triggering angle is increased to $120^{\circ}$ (interval 3 - 4 sec.), the power factor decrease to 0.41 .
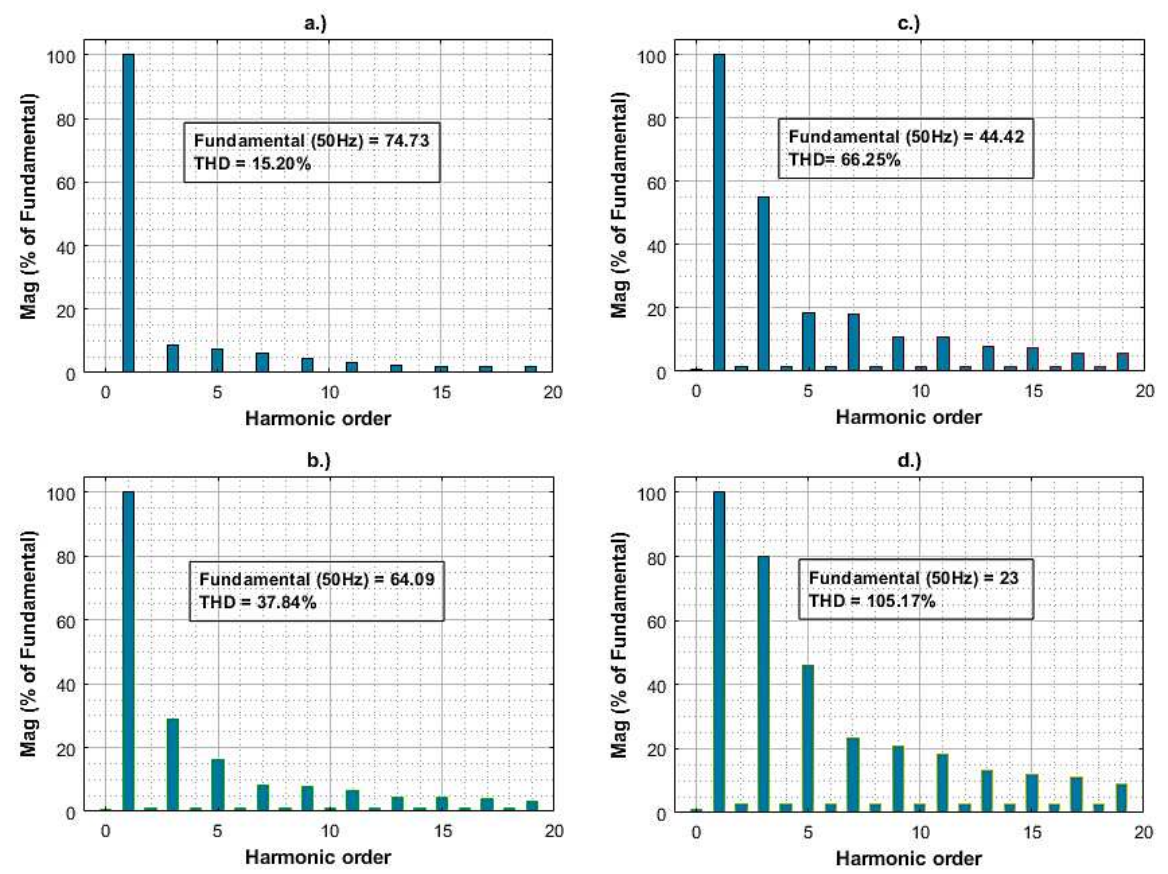

Figure 11. Change of total harmonic distortion of the output voltage, a.) $\alpha=30^{\circ}$, b.) $\alpha=60^{\circ}$, c.) $\alpha=90^{\circ}$, and d.) $\alpha=120^{\circ}$ 


\begin{tabular}{|c|c|c|}
\hline & $\begin{array}{l}\text { BŞEÜ Fen Bilimleri Dergisi } \\
7(1), 306-318,2020\end{array}$ & $\begin{array}{l}\text { BSEU Journal of Science } \\
\text { DOI: } 10.35193 / \text { bseufbd } 647049\end{array}$ \\
\hline & & 58-7575 (http://dergipark.gov.tr/bseufbd) \\
\hline
\end{tabular}

Figure 11, shows the results of the harmonic analysis with the help of Simulink FFT analysis of the designed single-phase voltage controller based on the simulation results. Figures 11a, 11b, 11c, 11d show harmonic analysis of the output voltage for phase triggering angles of $30^{\circ}, 60^{\circ}, 90^{\circ}$ and $120^{\circ}$, respectively. In Figure 11, the total harmonic distortion (THD) is $15.20 \%$ when the phase triggering angle is $30^{\circ}$, the total harmonic distortion (THD) increases to $105.17 \%$ when the phase triggering angle is increased to $120^{\circ}$. Therefore, increasing phase triggering angle is negatively affect both power factor and power quality.

a.)

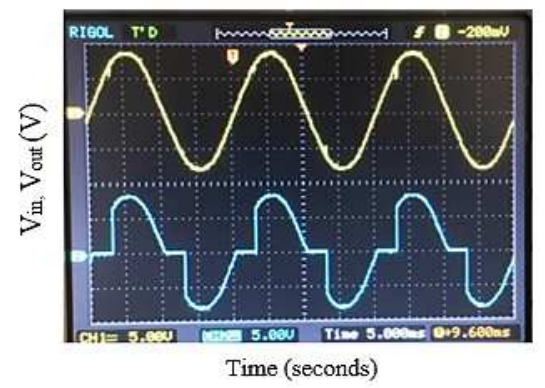

c.)

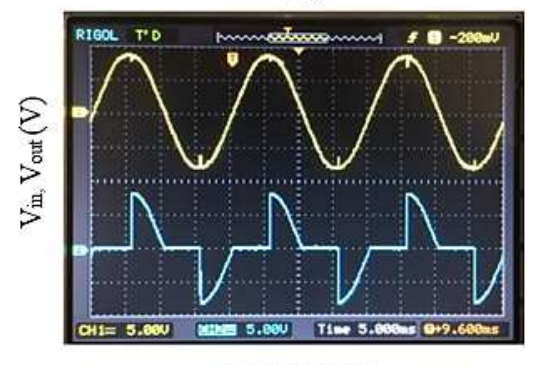

Time (seconds)

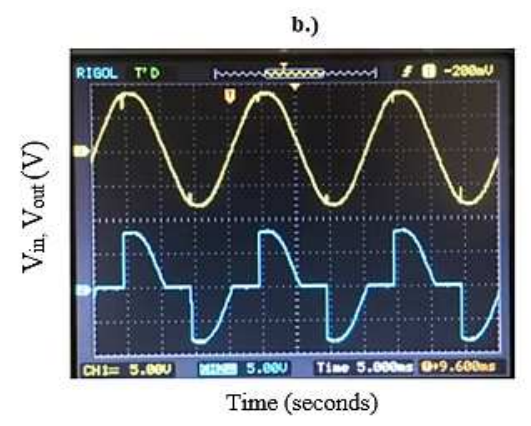

d.)

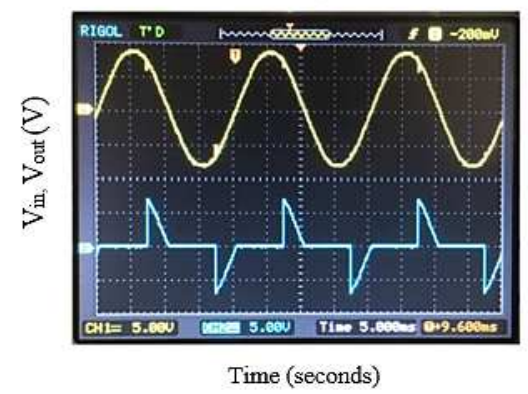

Figure 12. Change of output voltage with respect to input voltage in the designed experimental model, a.) $\alpha=30^{\circ}$, b.) $\alpha=60^{\circ}$, c.) $\alpha=90^{\circ}$, and d.) $\alpha=120^{\circ}$

The results obtained from the experimental setup are shown in Figure 12. The power factor and the effective values of the output voltage and current obtained from the simulation and experimental model are given in Table 1.

Table 1. The effective values of the output voltage, output current and power factor

\begin{tabular}{ccccccccc}
\hline $\begin{array}{c}\text { Phase } \\
\text { Triggering } \\
\begin{array}{c}\text { Angle } \\
\text { (degree) }\end{array}\end{array}$ & $\begin{array}{c}\text { Phase } \\
\text { Triggering } \\
\text { Angle (sec.) }\end{array}$ & $\begin{array}{c}\text { Output } \\
\text { Voltage } \\
(\mathbf{V})\end{array}$ & $\begin{array}{c}\text { Output } \\
\text { Current } \\
(\mathbf{A})\end{array}$ & $\begin{array}{c}\text { Power } \\
\text { Factor } \\
(\mathbf{P F})\end{array}$ & $\begin{array}{c}\text { Output } \\
\text { Voltage } \\
(\mathbf{V})\end{array}$ & $\begin{array}{c}\text { Output } \\
\text { Current } \\
(\mathbf{A})\end{array}$ & $\begin{array}{c}\text { Power } \\
\text { Factor } \\
(\mathbf{P F})\end{array}$ \\
\hline 30 & 0 & 53.95 & 0.539 & 0.970 & 55.1 & 0.55 & 0.974 \\
\hline 60 & 1 & 48.81 & 0.488 & 0.873 & 49.4 & 0.49 & 0.876 \\
\hline 90 & 2 & 38.45 & 0.384 & 0.684 & 39.3 & 0.39 & 0.687 \\
\hline 120 & 3 & 23.97 & 0.239 & 0.412 & 24.38 & 0.24 & 0.414 \\
\hline
\end{tabular}

\section{CONCLUSION}

In this study, single-phase AC voltage controller with phase angle controlled is examined both in simulation and experimentally. The voltage controller circuit is formed by connecting the two thyristors antiparallel. The load is selected as pure resistive. The phase triggering controller is designed to achieve the desired 
voltage level. The effective value of the output voltage is controlled by reference triggering angles applied to the phase triggering controller. The effects of the change of phase triggering angles on both power factor and total harmonic distortion have been demonstrated. Both the simulation and experimental results show that the phase triggering angle is inversely proportional to the power factor of the system. Increasing the phase triggering angles also significantly increased the total harmonic distortion in the output voltage. Simulation results are verified with the experimental results. When the results obtained are evaluated together, it can be said that phase triggering control is still effective in controlling the effective value of the output voltage. However, taking into account the power factor and total harmonic distortion of the system is very important for the efficient operation of the voltage controller.

\section{REFERENCES}

[1] Rashid, M. H. (2014). Power Electronics Devices, Circuits, and Applications. London Pearson Education, Fourth Edition, 552-596.

[2] Bodur, H. (2012). Güç Elektroniği Temel Analiz ve Sayısal Uygulamalar. Istanbul Birsen Yayınevi, 135178.

[3] Thanyaphirak, V., Kinnares, V., Kunakorn, A. (2012). PWM AC chopper control schemes for energy saving of single-phase induction motors. 10th International Power \& Energy Conference (IPEC), 12-14 Dec. 2012, Vietnam, 82-87.

[4] Kalla, U. K., Kumar, P., Suthar, R., Bhardwaj, T. (2018). Power Quality Analysis of Single Phase Conventional AC Chopper Based Small Power Heating Oven Systems. 8th IEEE India International Conference on Power Electronics (IICPE), 13-15 Dec. 2018, India, 1-6.

[5] Duranay, Z. B., Güldemir, H. (2018). AA Kıyıcı Beslemeli Bir Fazlı Asenkron Motorun Hız Kontrolü. Fırat Üniversitesi Mühendislik Bilimleri Dergisi, 30, 111-119.

[6] Kumar, P. S., Mahendar B., Shruthi M. (2014). Design and Implementation of AC Chopper. International Journal of Emerging Engineering Research and Technology, 2, 36-41.

[7] Electrical Concepts. Switching Characteristics of SCR. (2018). https://electricalbaba.com/switchingcharacteristics-scr/. 4-Oct-2019.

[8] All About Circuits. The Basics of Power Semiconductor Devices: Structures, Symbols, and Operations. (2015). https://www.allaboutcircuits.com/technical-articles/a-review-on-power-semiconductor-devices/. 4Oct-2019.

[9] Chaturvedi, K., Mahor, A., Dwivedi, A. D. (2012). Analysis of Impact of Triggering Angle on An AC Chopper in terms of Harmonic Distortion \& Power factor. International Journal of Scientific Engineering and Technology, 1, 118-122.

[10] Arifoğlu, U. (2012). Matlab 7.14 Simulink ve Mühendislik Uygulamaları. Istanbul Alfa Basım Yayım Dağıtım. 